\title{
The Role of Brand Authenticity as a Part of Contemporary Marketing in Egyptian Destination Marketing
}

\section{Jala Morsy Ibrahim}

Researcher, Tourism Studies Department

Faculty of Tourism and Hotels, Alexandria University

\section{Nermin Abdel-Hamid Morsy}

Associate Professor, Tourism Studies Department

Faculty of Tourism and Hotels, Alexandria University

\section{Hala Nabil Hilaly}

Professor, Tourism Studies Department

Faculty of Tourism and Hotels, Alexandria University

\begin{abstract}
Authenticity is an essential human aspiration, making it a cornerstone of contemporary marketing and a major factor for brand success. So, consumers have become more concerned with the ' authenticity' concept in a world where they doubt the credibility of the value of mass production. Consumers also seek authenticity in souvenirs, tourist experiences, brands, television showsand personal possessions. Hence, local products are a symbol of authenticity including the culture and habits of the destination also local products have a deep connection with a place, its people, their ways of life at a certain period of time. So, the purpose of the research is to investigate the impact of using local products as an authentic brand on promoting Egyptian tourist destination and explore the effect of Globalized authenticity on the local product in Egypt.
\end{abstract}

Key words: Authenticity, local product, souvenirs, contemporary marketing

\section{Introduction}

Many scholars in the marketing field and consumer research agreed that authenticity is an important topic for study, which is identified by a number of scholars as a pivotal attribute of contemporary life (Grayson and Martinec,2004; Kadirov, 2010).

In fact, one of the most main topics in contemporary marketing is the tension between authenticity and in authenticity. This tension has been intensified by technological progress, which facilitated the effective simulation of authenticity (Brown,2001). Consequently, it has been verified that authenticity is as an essential human aspiration, making it "one of the cornerstones of contemporary marketing" (Brown et al., 2003, p 21) and stressing on its importance to brands since uniqueness is an important aspect of brand identity (Brown et al.,2003). So, consumers seeking for authenticity constantly (Grayson and Martinec, 2004; Jugard and Modig,2009) because they believe that authentic products and services give more value for money as they are more quality and more reliable (Jugard and Modig,2009). 
A consumer-research studies showed that consumers also seek authenticity in souvenirs, tourist experiences, brands (Holt,2002), television shows (Kozinets,2001) and personal possessions (Grayson and Shulman, 2000). Hence, local products are a symbol of authenticity including the culture and habits of the destination also local products have a deep connection with a place, its people, their ways of life at a certain period of time (Drakopoulos,2008). Moreover, local products connected with community'stradition, manners and its customs (Velissariou and Mpara,2014). Although brand authenticity is gaining increasing interest in consumer behavior research, but is still limited (Morhart et al., 2014). The previous researches present a differentiated understanding of authenticity in general. Therefore, light will be shed on brand authenticity in particular.

\section{The concept of brand authenticity}

Consumers have become more concerned with the 'authenticity' conceptualized day by day in a world in which they question the credibility of the value of mass production (Rose and Wood, 2005). Why does brand authenticity matter?! First, consumers desire it because they use certain brands to achieve selfauthentication (or confirm their desired identity). Second,traditional brand which reflects the identity falls apart due to increased globalization, decreased barriers between countries (Arnould and Price, 2000). Thus, brand authenticity has become an important dimension in contemporary consumer behavior (Gilmore and Pine, 2007).Moreover, authentic brands enable consumers to connect to people; time, place, and culture are viewed as genuine partners, led to increasing emotional bonds between customer and brand. Consequently, authentic brands are critical to the identity of today's consumer (Beverland and Farrelly, 2010).
Brand authenticity is defined as "consumer judgment about the extent to which a brand is considered to be authentic or inauthentic" (Kadirov, 2010, p2). Also, brand authenticity refers to "The degree to which a brand object is perceived by its target audience to be original, honest, of high quality, and admirable" (Akbar, 2016, p34).Furthermore, it has been defined as "a subjective evaluation of genuineness ascribed to a brand by consumers" (Napoli et al., 2014, p1091). Despite the multiple brand authenticity concepts, it has been found that brand authenticity is based on the evaluations of individuals rather than being solely related to the inherent characteristics of the brand (Bruhn et al., 2012).Finally, brands can acquire an aura of authenticity through a "... commitment to traditions, a passion for craft and production excellence and the public disavowal of the role of modern industrial attributes and commercial motivations" (Beverland, 2005, p1008).

\section{The consumer quest for authentic brand}

Authenticity is described as a quest (Charles,2014). The quest for authenticity may be understood as a response to the threats of inauthenticity because of mass production (Rose and Wood,2005). Hence, Charles (2014) linked between aquest for authenticity and achievement consumer goals to obtain authentic products.

Consumers prefer authentic and unique products (Liao and Ma,2009), which use handmade methods, ancient traditions, and natural ingredients (Napoli et al.,2014) these products remain loyal to their original designs, and evolving slowly to reflect modern times rather than changing consumer fashions (Beverland et al.,2008). Radical changes to designs can confuse customer and lead to questions about a brand's authenticity (Napoli et al.,2014). Thus, marketers have begun to 
offer perfect quality products with real life stories and brand history to their target audience (Kwok et al.,2017).

Furthermore, it has been agreed that consumer's quest for authentic brand for several reasons: First, is feeling in control of their personal identity, by consuming authentic brand (Charles, 2014), authentic brands achieve self-authentication and confirm the desired identity for consumer (Arnould and Price, 2000). Second, consumers' desire communal connections, authentic brands enable consumers to connect with people, time, placeand culture (Beverland and Farrelly, 2010). Third, is feeling ethical virtue when making conscious choices to consume authentic products (Charles,2014; Kwon and Kwon,2015).

Consequently, scholars from this stream of literature tried to answer the question:Do consumers distinguish the authenticity of the product/service?(Pattugliaand

Mingione,2016).To answer this question, scholars investigated the consumer's ability to determine the difference between real or fake (Brown et al., 2003), it has been revealed that consumers struggle to differentiate the real from the fake (Pattuglia and Mingione, 2016). Liao and Ma (2009) confirmed that consumers are able to distinguish the subtle differences between authentic products and massproduced ones.

Finally, it has been revealed that brand authenticity affects purchase intents (Napoli et al., 2014), which led many marketers to invest in "authentic branding strategies"(Beverland,2009). Since authentic brands are critical to the identity of today's consumer (Beverland and Farrelly, 2010).Therefore, light will shed on souvenir authenticity and its impact on the intention to purchase

\section{Local product as an authentic brand}

Souvenir is one of important elements of the travel experience which enhance identity, reflect destination image and excite positive memories of tourist vacation (Olalere,2017). Also, souvenirs symbolize native customs and local residents, as well as, a valued souvenir (AbuElEnain and Yahia, 2015). In addition, tourists like to remind special moments in their lives through the acquisition of souvenirs as well as using souvenirs as gifts for friends and relatives (Wilkins,2010). Tourists also seeking an authentic experience extended to souvenir purchase such as local food, clothes and local craft (Ramkissoon and Uysal,2010).

Souvenir shopping represents a significant amount of tourist's total expendituresince it is considered one of the most important items after lodging, food, and entertainment (Shen, 2011). According to Gorden, (1986) souvenir serves as a remembrance, extraordinary experience, special moments and events for tourist. Thus, souvenirs reconstruct authenticity by reinterpreting and transferring the authenticity inherent in cultural and historical elements (Kaya and Yagiz, 2015). Table (1) summarizes the attributes of souvenirs which are important to tourists. Souvenir attributes refer to the varied characteristics of a product that influence a customer's decision to purchase the product or not (Swanson and Horridge, 2004)

Table (1) Product attributes of souvenirs

\begin{tabular}{|c|l|}
\hline Graburn, 1976 & $\begin{array}{l}\text { Easily portable, relatively inexpensive, } \\
\text { understandable, cleanable, and usable } \\
\text { upon returning home }\end{array}$ \\
\hline $\begin{array}{c}\text { Littrell et al., } \\
\mathbf{1 9 9 4}\end{array}$ & $\begin{array}{l}\text { an item, uniqueness of the product, } \\
\text { whether the product made by a well- } \\
\text { known producer, product present new } \\
\text { idea }\end{array}$ \\
\hline $\begin{array}{c}\text { Turner and } \\
\text { Reisinger, } \\
\mathbf{2 0 0 1}\end{array}$ & $\begin{array}{l}\text { Value (quality), product display } \\
\text { characteristics display, } \\
\text { packaging، size) and uniqueness } \\
\text { (memory of the trip, unique nature) }\end{array}$ \\
\hline
\end{tabular}


Despite the importance of souvenirs, there are limited studies on souvenir authenticity and how they influence tourists' decisions to purchase souvenirs (Olalere, 2017).So, the following part will revealthe levels of souvenir authenticity

\section{Levels of souvenir authenticity}

Cohen (1979) divided the traveler into modes based on travel experience (cultural tourists and recreational tourists). These travel modes are used to determine the level of authenticity. Cultural tourists have special interests and devote great efforts seeking for an authentic experience extended to souvenir purchase (Ramkissoon and Uysal,2010). They began to seek authentic traditional products, which meet their personal needs and express the traditional way of life (Morris and Young,2000). Accordingly, the cultural tourist tends to be positively associated with high level of authenticity (Goo and Shen, 2011).

Recreational tourists seek to visit friends, relatives and go to resort such as seaside, skiing, health, spa, which has little to do with authenticity (Cohen, 1979). The recreational tourist tends to be positively associated with low level of authenticity (Goo and Shen, 2011).It has been argued that recreational tourists seek play, pleasure, entertainment and relaxing experience(Urry,2001).

Moreover, Goo and Shen (2011) classified souvenirs into two types of souvenirs are:ethnic souvenirs and commercial souvenirs.

In fact, ethnic souvenirs have long been a symbol of identity (Timothy, 2005). Production of ethnic souvenirs creates positive images of the tourist destination and portrays local authenticity besides creating an opportunity to communicate with tourists. Accordingly, the ethnic souvenirs are positively related to the high level ofauthenticity (Goo and Shen, 2011). On the contrary, commercial souvenirs are manufactured on a massive scale and do not portray local originality. Accordingly, the commercial souvenirs are positively related to the low level ofauthenticity (Goo and Shen, 2011).

In these instances, the level of authenticity affects the souvenir purchase intent, whether authentic or inauthentic. Another factor affecting souvenir purchase intent is the country of origin. So, the following part will illustrate the importance of country of origin for consumers and their intent to purchase.

\section{The effect of globalized authenticity on local products}

Nowadays the world is the subject of world shrinkage. Distances are getting shorter and things are moving closer (Larsson,2001). The whole world is currently moving towards a single global market, referred to as the Global Village. This is called globalization(Verick, 2006). Globalization refers to "increasing connectivity, integration and interdependence in the socio-economic, technological, cultural, political and ecological spheres" (Jena, 2010,p120). This concept has many subprocesses which include, enhanced economic interdependence, increased cultural influence, rapid advancement of information and communication technology in a way that is shrinking the world to small size (Ali et al.,2012).

Globalization became one of the fashionable buzzwords these days, which put the end of geography and the death of distance.Also, globalization has put both east and west into one compartment and made it a global village (Vats, 2014). In the 20th century, companies used to design and manufacture their products 
locally. Consumers were accustomed to trust their local brands more than any other and were also less exposed to foreign brands. However, globalization challenged this perception, which led to the growing differentiation between the country of origin of the brand, the place of design and production, which created more confusion for the consumer (Scriven, 2014).

In addition, some scholars argued that a new global market would arise. This market should be based on uniform products and services. Products should be standardized, reliable and low-priced. It has been argued that informed customers heading towards a "convergence of tastes" (Levitt, 1983). So, companies should sell the same things in the same way everywhere. However, other scholars argued that through this strategy, consumers would stop feeling a connection with the product (Dumitrescu and Vinerean,2010). In order to keep successful, brands should take into account differences in the economic, political, social and cultural environment around the world. This strategy gives answers to the opposite trend of globalization because countries take into account that the identity is very important for people and countries (Dumitrescu and Vinerean, 2010).

In the globalization times, in various countries small scale industries faced enormous problems and failed to compete with the Chinese companies which entered the market with its low-cost products. This unstable situation appears in the artisans and the crafts when globalization separated the crafts from the actual artisans (Vats, 2014). Today, globalization is also described as a drive for profit achievement and replacement of the local culture by the global (Vats, 2014). It became common to find the so-called local souvenirs with label denoting a foreign manufacturer (Shen, 2011).
In addition, globalization has resulted in the loss of many unique and specific local products (Tregear et al., 1998). With the loss of numerous unique local products, consumers' option to preserve and support their own identity and cultural, as well as, enhance the heritage, reduced the potential for losing of their cultural identity (Ittersum, 2002). Therefore, they should give more interest to their own local culture and community in order to reassure their own identity and preserve their cultural boundaries (Ittersum, 2002).

Due to globalization, consumers have more problems in understanding the country of origin (Cai et al.,2004). Several researches have been concerned with the importance of the country of originrelying on the fact thatevery country has its own culture that affect consumer's perception of the product (DikčiusandStankevičienè,2010). Hence, the following part will discuss the importance of country of origin for consumers.

Made in' is more important than ever to illustrate, the country of origin is the term used to describe where products originate from agriculture, manufacturing or production. It is referenced by the term 'Made In' (Elliott and Cameron, 1994). Several studies have shown that consumers are very sensitive to the origin of the product (Newman and Dhar,2014), where the words 'Made' and 'In' are used to transfer important information about a product and a brand (Velissariou and Mpara,2014). Moreover, 'Made In' has a greater influence and importance for consumers because it can qualify key considerations such as safety, quality, and ecological standard in consumers' minds at the point of purchase (Cai et al.,2004). Actually,scholars argue that purchasing a country's product is a way of supporting its economy (Verlegh and Steenkamp, 1999). 
Nevertheless, it is becoming hardly to find things that are truly unique and authentic. In fact, those is exactly what experienced tourists are looking for, and are willing to pay high price for products that reflect that experience, because authentic local products have a deep association with a place, its people, their ways of life and/or at certain periods of time (Drakopoulos, 2008). Moreover, another apparent advantage of local products is that many of them are connected with community, tradition, ethics and customs of a region (Velissariou and Mpara,2014).

Absolutely, there is a strong relation between the country of origin and the perception of the quality of a product, also 'Made in' affects purchase decisions.(Love and Sheldon, 1998).It has been found that country of origin influence consumers' beliefs about tangible product attributes, and in turn affects their overall evaluation (Bilkey and Nes,1984). It has also been argued that the information on country of origin is very important to a tourist's evaluation of the souvenir.Tourists use country of origin as a key factor in the purchase decision-making process (Goo and Shen,2011).

Finally, some critics view the "Made in China" tag unfavorable and suggest that the souvenirs must be manufactured in the country of origin, because its reflect country of origin's image (Goo and Shen,2011) and identify the cultural and geophysical features of a product. Accordingly, products become unique and acquire identity and thus the consumer refuses to substitute these products with others which are similar (Velissariou and Mpara,2014). Moreover, The European Union grants certificates of protected designation of origin for the protection of the diversity and quality of products, in order to ensure thatconsumers get products which respect the basic determinants of quality, authenticity and traditional terms (Velissariou and Mpara,2014). Studies confirm that consumers now are more aware of the origin of a product and they are expecting the products to be manufactured properly (Goo and Shen, 2011).

\section{Methodology}

This study has adopted a mixed methods approach which focuses on collecting, analyzing, and mixing both quantitative and qualitative methods in a single study (Leech and Onwuegbuzie,2009). Firstly, the questionnaire has been distributed to 200 of tourists to measure souvenirs-related issues, including planning to purchase souvenirs, identifying the importance of souvenirs for tourists, as well as, the importance of authentic souvenirs from a tourist's perspective in order to clarify the impact of using local products as an authentic brand on the promotion of tourist destination in Egypt.

Moreover, chi-square test has been used to measure the association between knowledge of tourists the most important souvenirs that distinguish Egypt, and the preferences of buying souvenirs. It also has been used to measure the association between the reasons for buying souvenirs and possibility purchase Chinese souvenirs at a low price.In addition, conducting interviews with 20 of souvenir sellers, in order to explore the effect of globalized authenticity on the local product in Egypt, as well as, identify the most important obstacles facing the owners of souvenirs and antiquities shops.

The study was restrictedto two cities, Cairo and Sharm El-Sheikh. Cairo is characterized by the existence of a large number of bazaars for souvenirs, especially in the Khan al-Khalili region. WhileSharm El-Sheikh is the most popular city and attracts a large number of tourists annually (State Information Service) 


\section{Data analysis and Discussion}

\subsection{Questionnaire analysis}

The tourist sample is 200 questionnaires including74 Arabians tourists representing $37 \%$ from different nationalities (13 Syrian, 19 Libyan, 21 Jordanian and 21 Iraqi) and 126 Europeans tourists representing 63\% from different nationalities (72 Ukrainian, 38 Italian and 16 German), also the questionnaire include 109 male and 91 female.

* Regarding souvenirs-related issues, including planning to purchase souvenirs

The analysis shows that $90.5 \%$ of tourists prefer to buy souvenirs during their trip. This means that shopping souvenirs are a major tourist activity during the trip.

In addition, the analysis indicates that the most important factors in selecting souvenirs are (cost $24 \%$ - authenticity $31.5 \%$ - quality $19.5 \%$ - design 5\%-practical use 7\%- favorable 5\%portability $8 \%$ ). The analysis also shows that the three important factors for tourists are (authenticity $31.5 \%$, followed by cost $24 \%$ and quality $19.5 \%$ ). This means that authenticity is the most important factoraffecting souvenirs selection, which indicates that tourists strongly associate with the authenticity of a souvenir which represents the traditional culture and souvenirs made locally in the place that they have visited (Setiyati and Indrayanto, 2011).

Furthermore, the analysis shows the amount of money spent by tourists to buy souvenirs during their trip. $33.5 \%$ of tourists spend (less than 100\$) during their trip, 64.5\% spend ( $100 \$$ to $300 \$$ ) and $2 \%$ spend ( $300 \$$ to $500 \$$ ). This means that souvenirs are of great interest to tourists during their trip.This result also pointed to the economic benefits of buying souvenirs includingincome generation, tax revenue and improved standard of living as
Richard(2007); Mahgoub and Alsoud (2015) argued.

Concerning the importance of an authentic souvenirs for tourists and knowledge of the most important local products in Egyp.

The analysis shows that $80.5 \%$ of tourists prefer to buy homemade souvenirs during their trip in Egypt, while $19.5 \%$ of tourists don't insist on buying souvenirs made locally. This result indicates that local products are more than souvenirs as sources of livelihood; they are expressions of local cultures, community tradition and conveying significant cultural messages between host and guestsas Drakopoulos (2008) pointed.

In addition, the analysis shows that $95.5 \%$ of tourists who visit Egypt know the most important souvenirs that distinguish it, includePharaonic statues, copper crafts, papyrus, jewelery, perfumes, local food, clothes, handicrafts, leather crafts, seashells, marble and porcelain, while $4.5 \%$ of Europeans tourists don't know the most important souvenirs that distinguish Egypt. This confirms that souvenirs provide an excellent opportunity to potentially worldwide advertising to promote the tourist destination.

Moreover, the analysis shows that it is not possible for $69.5 \%$ touriststo purchase Chinese products for low price while $30.5 \%$ tourists buy Chinese products for the low price. This result confirms the importance of authentic souvenirs.This result also confirms what has already been mentioned by Vato (2014) that in various countries' small scale industries facing enormous problems and failed to compete with the Chinese companies which entered the market with its low-cost products. This unstable situation appears in the artisans and the crafts when globalization separated the 
crafts from the actual artisans. Consequently, $30.5 \%$ of tourists buy Chinese products for the low price.

Finally, the analysisillustrates that $63.5 \%$ of tourists buy souvenirs for memory and $35.5 \%$ of tourists buy souvenirs as a gift for friends, family members, girl/boyfriend and work colleagues. Finally, only $1 \%$ of Europeans tourists buy souvenirs for social obligation. This result confirms that souvenirs represent evidence which is usually used as an approval that someone achieved particular experience.

\subsection{Chi-Square test}

The significance level of the Chi- Square test is 0.05.Firstly, Chi-Square test has been used to measure the association between knowledge of tourists,the most important souvenirs that distinguish Egypt, and the preference of buying souvenirs. Table (2) shows that $\mathrm{X}^{2}=6.226$ and $\mathrm{P}=0.013$ (where $\mathrm{P}<0.05$ ) ) which means that there is a significant association between knowledge of tourists the most important souvenirs that distinguish Egypt, such as (Pharaonic statues, copper crafts, papyrus, jewelry, perfumes, local food, clothes, handicrafts, leather crafts, sea shells, marble and porcelain) and the preference of buying souvenirs,. Consequently, souvenirs provide an excellent opportunity to potentially worldwide advertising to promote the tourist destination. This result is largely consistent with Nyffenegger and Steffen (2010) that welldesigned souvenir products have strong potential to support a destination's image and marketing for a long time as well as promote the tourist destination indirect way but efficient manner.

Furthermore,chi-square test has been used to measure the association between the reasons for buying souvenirs and the possibility of purchasing Chinese souvenirs at a low price.
Table (2) shows that $\mathrm{X}^{2}=57.496$ and $\mathrm{P}=0.000$ where $\mathrm{P}<0.05$ which means that there is a significant association between reasons for buying souvenirs and possibility of purchasing Chinese souvenirs at a low price where $30.5 \%$ tourists prefer to buy Chinese products for low price especially tourists who are buying souvenirs as a gift. This result is consistent with what has already been mentioned in Setiyati and Indrayanto (2011) as they confirmed that price is one of the most important factors that impact on purchasing souvenirs. The expensive price of locallymade souvenirs may affect tourist's willingness to buy local souvenirs. In addition, they confirmed that tourists who are price sensitive may be turning to buy imported souvenirs instead of authentic made souvenirs. Especially tourists that need to buy a large number of souvenirs as gifts for other people.

Table (2) The Chi-square test

\begin{tabular}{|l|l|l|l|}
\hline & Value & $\begin{array}{c}\text { Asymp. } \\
\text { Sig. (2- } \\
\text { sided) }\end{array}$ & $\begin{array}{l}\text { Likelihoo } \\
\text { d Ratio }\end{array}$ \\
\hline $\begin{array}{l}\text { The association } \\
\text { between knowledge of } \\
\text { tourists the most } \\
\text { important souvenirs } \\
\text { that distinguishes } \\
\begin{array}{l}\text { Egypt and the } \\
\text { preference of buying } \\
\text { souvenirs association }\end{array}\end{array}$ & & $0.013^{*}$ & 0.042 \\
\hline $\begin{array}{l}\text { The most } \\
\text { between the for } \\
\text { important reason for } \\
\text { buying souvenirs and } \\
\text { possibility purchase } \\
\text { Chinese souvenirs for a } \\
\text { low price } 57.496\end{array}$ & $0.000^{*}$ & 0.000 \\
\hline
\end{tabular}

Significant at 0.05 significance level 


\subsection{Interview analysis}

It has been conducted interviews with 20 of souvenir sellers divided into 13 interviews in Khan El-Khalili region in Cairo and 7 interviews with souvenir sellers in Sharm ElSheikh.

Most of souvenir sellers mentioned, during the interviews, they sell a different number of souvenir products, these products are represented in Pharaonic statues, copper crafts, papyrus, medals, porcelain, seashells, rocks and Pharaonic accessories, while a few numbers of souvenir sellers sell handmade textile, leather,perfumes and pottery. The following part will identify the 'themes' in the interview data through a process of coding and categorize data.

\section{Pharaonic souvenirs dominate the market:}

All souvenirs sellers in the research sample agreed that Pharaonic souvenirs dominate the Egyptian market such as Pharaonic statues, papyrus with Pharaonic inscriptions, Pharaonic accessories and medals with Pharaonic shape.

Chinese products are predominant in the Egyptian market:

Souvenir sellers totally agreed that the increase in the dollar's exchange price affected positively on them. The research found that 95\% souvenir sellers relied mainly on Chinese products before the noticeable increase in the dollar's exchange price due to their cheap price, such as Pharaonic statues, Pharaonic accessories and medals instead of Egyptian products. While 5\% souvenir sellers sell Egyptian products only. But after the increase in the dollar's exchange price, $40 \%$ souvenir sellers became relying on Egyptian products instead of Chinese products.

Moreover, 95\% souvenir sellers emphasize that Chinese products are concentrated on
Pharaonic souvenirs such as Pharaonic statues, accessories and medals, while copper crafts and leather products are Egyptian.

Chinese souvenirs versus Egyptian souvenir:

All of souvenir sellers confirmed that Chinese products have a negative impact on Egyptian products, where $40 \%$ emphasized that many of souvenirs shops change the "Made in China" label by" Made in Egypt" and sell Chinese products as a local product. This is known as commercial fraud which affects the reputation of the Egyptian product. In fact, 35\% souvenir sellers confirmed that Chinese products are cheaper than Egyptian products. Finally, 25\% stressed that a lot of workshops end their business because of Chinese products.

The souvenir appearance is vital:

95\% souvenir sellers emphasize that Egyptian products are characterized by good material and quality, but had poor finishing, while Chinese products are characterized by excellent finishing and attractive appearance, while having a poor material with low quality. Therefore, the majority of tourists are fooled by the attractive appearance. Absolutely, most souvenir sellers emphasized that all Egyptian products are handmade, while on the contrary, Chinese products are manufactured by machines, so characterized by attractive appearance.

Egyptian products are still preferable:

$65 \%$ souvenir sellers emphasize that tourists prefer Egyptian products, even if they are expensive or have bad finishing since most Egyptian products are handmade, unlike Chinese products. Likewise, they emphasized that tourists prefer to purchase souvenirs are locally made. While 35\% souvenir sellers emphasized that tourists prefer Chinese products in the case of buying a large number of products as gifts for friends and relatives 
because Chinese products are cheaper than Egyptian products.

Challenges facing local souvenirs in the market:

All souvenir sellers agreed that there are many challenges facing them in the Egyptian market. These challenges are presented in the government negligence, lack of skilled labor, the spread of Chinese souvenirs in the market, lack of raw materials and rise of its price. In addition to an increase of taxes, lack of facilities and equipment, political instability in Egypt, lack of marketing, as well as a lack of innovation. Finally, the spread of peddlers and beggars in the markets.

\section{Results and discussion}

The results of the study confirm that souvenirs are an integral part of the tourism experience, as $90.5 \%$ of tourists prefer to buy souvenirs during their trip.

Actually, the results confirm that tourists strongly associate with the authenticity of a souvenir, where $31.5 \%$ tourists put authenticity in priority when buying souvenirs followed by $24 \%$ to cost and $19.5 \%$ to quality. That is in addition to the fact that $80.5 \%$ tourists prefer buying made-locally souvenirs during their trip.

Moreover, the results of the study emphasize that souvenirs are considered a profitable economic activity, since $33.5 \%$ tourists spend less than $100 \$$ while $64.5 \%$ spend (100\$ to $300 \$$ ) and $2 \%$ spend ( $300 \$$ to $500 \$)$ on purchasing souvenirs during their trip. In addition, the results of the study confirm that souvenirs provide an excellent opportunity to potentially worldwide advertising to promote the tourist destination, as the results confirm that there is a significant association between knowledge of tourists concerning the most important souvenirs that distinguish Egypt and the preference of buying souvenirs $X^{2}=6.226$ and $\mathrm{P}=0.013$ (where $\mathrm{P}<0.05$ ). Also, the results confirm that $95.5 \%$ tourists who visit Egypt know that the most important souvenirs that distinguish it, including Pharaonic statues, Copper plates, Papyrus, jewelry, perfumes, local food, clothes, handicrafts, leather crafts, seashells, marble and porcelain. Thus, local souvenirs can be used as an authentic brand in promoting the Egyptian tourist destination.

Furthermore, the results of the study confirm that Chinese products have a negative effect on made- locally souvenirs.

$\checkmark$ The results confirm that there is a significant association between reasons for buying souvenirs and possible purchase of Chinese souvenirs at a low price, $\mathrm{X}^{2}=$ 57.496 and $\mathrm{P}=0.000$ (where $\mathrm{P}<0.05$ ) which means that tourists prefer to buy Chinese products at a low price especially tourists who are buying souvenirs as a gift.

Before the increase in the dollar's price 95\% souvenir sellers relied on Chinese products instead of Egyptian products and only 5\% souvenir sellers sold Egyptian products. While after the apparent increase in the dollar's price $40 \%$ souvenir sellers became relied on Egyptian products instead of Chinese products.

$\checkmark \quad 40 \%$ souvenir sellers emphasize that many of the souvenir shops replace the "Made in China" label by" Made in Egypt" and sell Chinese products as a local product.

$35 \%$ souvenir sellers confirm that Chinese products are cheaper than Egyptian products.

$25 \%$ souvenir sellers confirm that a lot of workshops end their business because of Chinese products.

On the other hand, the results of the study confirm the domination of Pharaonic souvenirs 
upon the market and the absence of other kinds of souvenirs such as metal work, local food, handicrafts, leather and clothes.

In addition, the results of the study confirm that local souvenirs had poor finishing, as $95 \%$ souvenir sellers emphasize that Egyptian products are distinguished by good material and quality, but have poor finishing, while Chinese products are characterized by excellent finishing and attractive appearance despite its bad material and low quality.

Finally, results of the study clarify the challenges facing souvenir sellers in the market. These challenges are represented in government negligence, lack of skilled labor, the spread of Chinese souvenirs in the market, lack of raw materials and increase of its price. In addition, an increase of taxes, lack of facilities and equipment, political instability in Egypt, lack of marketing and quality as well as a lack of innovation. Lastly, the spread of peddlers and beggars in the markets.

\section{Conclusion}

The expenditure on souvenirs is economically and socially important. Souvenirs are considered one of the favored tourism activities that form an integral part of the tourists' travel experience. Indeed, this study clarifies the problematic issue with regard to the growing number of imported souvenirs in the Egyptian market at a time, many countries are trying to capture a market share of tourist spending on souvenirs.

It has also been found that the existence of imported souvenirs within an Egyptian's tourism market may cause authenticity disturbance for tourists. The results of this study showed that tourists prefer authentic souvenirs despite the existence of many problems in the Egyptian local product. However, tourists prefer souvenirs which are represent the traditional culture and that are locally-made in the place that they have visited.

Furthermore, this study reveals that the Egyptian souvenirs are perceived as being of higher value than Chinese souvenirs. Egyptian souvenirs are characterized by high quality, being more authentic and more prestigious compared to Chinese souvenirs. Also, the study reveals that Egyptian souvenirs are more expensive than imported souvenirs. Therefore, this may influence the intention of pricesensitive tourists to buy imported souvenirs instead of buying authentic souvenirs. Especially tourists who need to purchase a large number of souvenirs as gifts for other people.

Conclusively, it has been found that souvenirs provide an excellent opportunity to worldwide advertisement with positive impact on promoting the tourist destination. As a matter of fact, local products are more than souvenirs as sources of livelihood; they are dynamic expressions of local and regional cultures, serving as sensitive indicators of relationships conveying significant cultural messages between host and guests.

\section{References}

1. AbuElEnain,E. and Yahia,S. (2015). The impact of handicrafts on improving the tourist experience , case study UAE handicrafts industry, International Journal of Science Research and Technology, Vol. 1, No. 2, pp. 32-37

2. Akbar,M. (2016). Reconceptualizing brand authenticity and validating its scale, master of science in management, University of LethbridgeLethbridge, Alberta, Canada.

3. Ali,A. Awdini,A. and Adan,H.(2012), The Effect of Globalization on Local Industries: A Case of Mogadishu Manufacturers,International Journal of Business and Management Tomorrow, Vol. 2, No. 11 .

4. Arnould,E. and Price,L. (2000).Authenticating acts and authoritative performances: Questing for self and community,in S. Ratneshwar, D.G. Mick, and C. Huffman (Eds), The Why of Consumption: 
Contemporary Perspectives on Consumer Motives, Goals, and Desires (pp. 140-163). London: Routledge.

5. Beverland, M. (2009), Building Brand Authenticity, 7 Habits of Iconic Brands, Palgrave Macmillan ,UK

6. Beverland, M.B. and Farrelly F.J. (2010). "The Quest for Authenticity in Consumption: Consumers' Purposive Choice of Authentic Cues to Shape Experienced Outcomes," Journal of Consumer Research, Vol. 36, No.5, pp.838-856.

7. Beverland,M.Lindgreen,A. andVink,M. (2008)."Projecting authenticity through advertising: consumer judgment of advertisers' claims", Journal of Advertising, Vol. 37, No. 1, pp. 5-15.

8. Beverland,M.(2005). Crafting Brand Authenticity: The Case of Luxury Wines, Journal of Management Studies, pp.1003-1029

9. Bilkey,W. and Nes, E.(1984). Coutry of origin effects on product evaluation, journal of international business study, pp. 89-95

10. Braun, V. and Clarke, V. (2006). Using thematic analysis in psychology. Qualitative research in psychology Vol.3, No.2, pp. 77-101.

11. Brown,S. Kozinets,V. and Sherry, J .(2003). Teaching old brands new tricks: retro branding and the revival of brand meaning, Journal of Marketing, Vol. 67, No.3, pp.19-33.

12. Brown,S.(2001), The Retromarketing revolution: l'imagination au pouvoir, International Journal of Management Reviews, Vol. 3, No.4, pp. 303-320

13. Bruhn,M. Schoenmüller,V. Schäfer,D. and Heinrich,D.(2012). Brand Authenticity: Towards a Deeper Understanding of Its Conceptualization and Measurement, Advances in Consumer Research, Vol. 40 ,pp.567- 576.

14. Cai,Y. Cude,B .and Swagler,R. (2004). Country-ofOrigin Effects on Consumers' Willingness To Buy Foreign Products: An Experiment in Consumer Decision Making, Consumer Interests Annual, Vol. 50, pp. 98-105. (cai- country of origin-pdf)

15. Charles,S. (2014).Understanding brand authenticity in specialized communities: An interpretive qualitative study of the Brit Iron Rebels Las Vegas Clan, Master thesis, University of Nevada Las Vegas.

16. Cohen,E. (1979). A Phenomenology of Tourist Experience,from the SAGE Social Science Collections.

17. Dikčius,V. and Stankevičienè,G.(2010). perception of country of brand origin and country of product manufacturing among lithuauanians and emigragrants from lithuauania, organization and markets in emerging economies, Vol. 1, No. 2, pp.108-122

18. Drakopoulos,G.(2008). Tourism and Handicrafts A Report on the International Conference on Tourism and Handicrafts, Published and printed by the World Tourism Organization, Madrid, Spain

19. Dumitrescu, L. and Vinerean, M. (2010). The glocal strategy of global brands. Studies in Business and Economics, pp.147- 155.

20. Elliott,G. and Cameron,R. (1994).Consumer Perception of Product Quality and the Country-ofOrigin Effect,Journal of International Marketing, Vol. 2, No. 2, pp. 49-62

21. Gilmore, J.H., and Pine, B.J. (2007). Authenticity: What Consumers Really Want, Boston: Harvard Business School Press.

22. Goo,Y. and Shen,M. (2011). The relationship between authenticity and the souvenirs purchase intent,Pan-Pacific Management Review, Vo1.14, No.2: pp.109-129

23. Graburn, Nelson H. H. (1976). Ethnic and Tourist Arts: Cultural Expressions from the Fourth World. Berkeley: University of California Press.

24. Grayson, K. and David, S. (2000). "Indexicality and the Verification Function of Irreplaceable Possessions: A Semiotic Analysis," Journal of Consumer Research, No.27, pp. 17-30.

25. Grayson,k. and martinec,R.(2004).Consumer Perceptions of Iconicity and Indexicality and Their Influence on Assessments of Authentic Market Offerings, journal of consumer research, Inc. Vol. 31, pp. 296-312

26. Holt, B. (2002). "Why Do Brands Cause Trouble? A Dialectical Theory of Consumer Culture and Branding," Journal of Consumer Research, pp.7090.

27. Ittersum.K, (2002). The Role of Region of Origin in Consumer Decision-Making and choice. [Proefschrift]. Wageningen, Mansholt Graduate School

28. Jena,P.(2010). Indian handicrafts in globalization times: an analysis of global- local dynamics , Interdisciplinary Description of Complex Systems Vol.8,No.2, pp. 119-137.

29. Jugård,A. and Modig,P.(2009). The Meaning of Authenticity in the Experience Industry -An exploratory study of Swedish concept restaurants, Master of Science in Tourism and Hospitality Management.

30. Kadirov,D. (2010). Brand Authenticity: Scale Development and Validation,pp.1-7

31. Kaya,C. and Yagiz,B. (2015).Appropriation in souvenir design and production: A study in 
museum shops,ITU A|Z , Vol. 12, No. 1 ,pp. 127 146

32. Kozinets,V. (2001). "Utopian Enterprise: Articulating the Meanings of Star Trek's Culture of Consumption," Journal of Consumer Research, pp.67-88.

33. Kwok,S. Maguire,K. and Shotte,D. (2017). Questing for Brand Authenticity of Luxury Products: Consumers' Goal-contingent Process as Self-image Conformation Online, Advances in Economics, Business and Management Research, pp.1-11

34. Kwon,Y. and Kwon,K. (2015). Consuming the Objectified Self: The Quest for Authentic Self, Asian Social Science; Vol. 11, No. 2, pp. 301-312

35. Larsson, T. (2001). The Race to the Top: The Real Story of Globalization, US: Cato Institute.

36. Leech, N. and Onwuegbuzie, A. (2009). A typology of mixed methods research designs, Qual and Quant, No. 43, pp. 265-275.

37. Levitt, Th. (1983). The Globalization of Markets, Boston: Harvard Business Review.

38. Liao,S. and Ma,Y.(2009). Conceptualizing Consumer Need for Product Authenticity, International Journal of Business and Information,Vol. 4, No. 1, pp. 89-114

39. Littrell,A. Luella,A. and Pamela ,B. (1994). What makes a craft souvenir authentic? Annals of Tourism Research, No.20, pp.197-215.

40. Love, L. and Sheldon,S. (1998). Souvenirs: Messengers of meaning. Advances in Consumer Research, Vol.25, pp. 170-175.

41. Mahgoub,Y. and Alsoud,K.(2015).The Impact of Handicrafts on the Promotion of Cultural and Economic Development for Students of Art Education in Higher Education,Journal of Literature and Art Studies, Vol. 5, No. 6, pp. 471479

42. Morhart, F. Mal“ar, L. Gu`evremont, A. Girardin, F. and Grohmann, B. (2014) Brand Authenticity: An Integrative Framework and Measurement Scale, Journal of Consumer Psychology, Vol. 25, No. 2 ,pp. 200-218.

43. Morris, C. and Young, C. (2000). Seed to Shelf, Teat to able, Barley to Beer and Womb to tomb: Discourses of Food and Quality Assurance Schemes in the UK, Journal of rural studies, Vol. 16, pp. 103-115.

44. Napoli,J.Dickinson,S.Beverland,M. and Farrelly,F.(2014). Measuring consumer-based brand authenticity,Journal of Business Research,Vol. 67, pp. 1090-1098
45. Newman,G.andDhar,R.( 2014).Authenticity Is Contagious: Brand Essence and the Original Source of Production,Journal of Marketing Research Vol. LI, pp. 371-386

46. Nyffenegger, F. and Steffen, D. (2010). Souvenirs local messages. An exploration from the design perspective. Proceedings of the Design and Semantics of Form and Movement (DeSForM) Conference, pp. 135-144.

47. Olalere F.E, (2017).Importance of Product Attributes for Souvenir Purchase Preferences: A Viewpoint of Foreign Tourists in South Africa,African Journal of Hospitality, Tourism and Leisure, Vol. 6 , No.3, pp. 1-10

48. Pattuglia,S. and Mingione,M.(2016). Towards a new understanding of brand authenticity: seeing through the lens of Millennials, track 14- branding and value co-creation throughic, XXVIII Sinergie Annual Conference Proceeding Management in a Digital World. Decisions, Production, Communication

49. Ramkissoon,H. and Uysal,M. (2010). Treating the role of authenticity in cultural tourism consumption: a case study of Mauritus, Tourism Analysis, Vol. 15, pp. 571-583

50. Richard, N. (2007). Handicrafts and employment generation for poorest youth and women,UNESCOIntersectoralProgramme on the Cross-Cutting Theme "Poverty Eradication, Especially Extreme Poverty",United Nations Educational, Scientific, and Cultural Organization Paris, No 17.

51. Rose,R. and Wood,S. (2005). Paradox and the Consumption of Authenticity through Reality Television, journal of consumer research, Vol. 32,pp.284-296

52. Scriven,J.(2014), The Impact of Globalization on the Consumer, Master thesis, Neumann University.

53. Setiyati,E. and Indrayanto,A. (2011), Outsourced Souvenirs: An Investigation towards Authenticity Anxiety and Tourist"s Purchase Behaviour, Proceeding of the International Conference on Social Science, Economics and Art, pp.196-201.

54. Shen,M.(2011). The effects of globalized authenticity of souvenir, International Journal of Innovative Management, Information \& Production, Vol. 2, No. 1, PP. 68-76.

55. Swanson, K.K. and Horridge, P.E (2004). A Structural Model for Souvenir Consumption, Travel Activities, and Tourist Demographics. Journal of Travel Research, vol. 42, pp.372-380.

56. Timothy, D. (2005). Shopping tourism, retailing, and leisure. Clevedan: Channel View Publications 
57. Tregear, A. Kuznesof, S. and Moxey, A. (1998). Policy initiatives for regional foods: some insights from consumer research. Food Policy, Vol.23, No.5, pp. 383-395

58. Turner, L.W. and Reisinger, Y. (2001). Shopping Satisfaction for Domestic Tourists, Journal of Retailing and Consumer Servies, Vol. 8, pp.15-27

59. Urry, J. (2001). The tourist gaze: Leisure and travel in contemporary societies. London:Sage.

60. Vats,N.(2014). Indian Handicrafts and Globalization: A Review, IOSR Journal Of Humanities And Social Science, Vol. 19, No. 1, pp. 40-43.

61. Velissariou,E. and Mpara,E.(2014).Local products and Tourism gastronomy in rural areas Evidence from Greece,MIBES international conference,pp.253-265

62. Verlegh, P.W.J., and Steenkamp, J.B.E.M. (1999). A review and meta-analysis of country-of-origin research. Journal of Economic Psychology, Vol.20, pp.521-546.

63. Wilkins, H. (2010). Souvenirs: What and Why We Buy. Journal of Travel Research, Vol. XX, No.(X), pp.1-9

\section{Websites}

1. State Information Service http://sis.gov.eg/Story/134542?lang=ar

2. State Information Service http://www.sis.gov.eg/Story/132731?lang=ar 